\title{
Design and Build a Multilevel Mace Nutmeg Dryer to Improve the People's Economy
}

\author{
Ihsan $^{1)}$, Dirja Nur Ilham ${ }^{2)}$, Reza Ade Putra ${ }^{3)}$, Rudi Arif Candra ${ }^{4)}$, Arie Budiansyah ${ }^{5)}$ \\ ${ }^{1224)}$ Politeknik Aceh Selatan, Indonesia ${ }^{3}$ Universitas Islam Negeri Raden Fatah, Palembang, Indonesia, \\ ${ }^{5}$ Universitas Syiah Kuala, Indonesia \\ 1)ihsan.poltas@gmail.com, ${ }^{2)}$ dirja.poltas@gmail.com, ${ }^{3)}$ rezaadeputra uin@radenfatah.ac.id, \\ ${ }^{4)}$ rudiarifcandra@gmail.com, ${ }^{5)}$ arie.b@unsyiah.ac.id
}

Submitted : Sep 30, 2021 | Accepted : Oct 5, 2021 | Published : Oct 11, 2021

\begin{abstract}
Nutmeg is a source of income for some people in South Aceh, and some types of nutmeg, like mace nutmeg, are of better quality. Mace nutmeg is also an agricultural community with great economic value and benefits for humans, as it can be processed into spices and herbs. A range of products includes nutmeg oil and medicines. The harvesting and drying of mace nutmeg, which is still considered a problem by nutmeg growers, cannot be isolated from the processing of the basic ingredients. The natural process of drying mace nutmeg involves the use of sunshine, which necessitates a considerable drying time. Therefore nutmeg farmers frequently complain of erratic weather, especially during the wet season. The constant rain can cause the mace to rot, causing the nutmeg farming community's revenue to become unstable. Methods and steps of research work starting from the study of literature, determination of design specifications, hardware design, software design, toolmaking, tool testing.Good results were reached with the dryness of the mace nutmeg, which can be adjusted, and without putting into account the weather in the drying process, which is usually done with the heat of the sun, per the results of the testing of the designed tools. The average dryness of mace nutmeg is at a temperature of 45 percent with a time of 4 hours and a capacity of 100 grams; according to the test results of the automatic mace drying machine, it produces 50 grams of dry mace.
\end{abstract}

Keywords: Arduino Uno; Heating element; DHT11; Fan Motor; Relay

\section{INTRODUCTION}

South Aceh is known as the "Land of Nutmeg" because it produces a lot of nutmegs. The finished product has a variety of distributions, including nutmeg seeds, mace nutmeg, nutmeg skin, and others, and during the drying process, the sun's heat is still a major factor in the weather. Mace nutmeg is a type of nutmeg with a high price tag, but owing to a process that is dependent on the weather, the quality of mace nutmeg is often reduced during the wet season.

Previous researchers have made many designs of dryers such asCorn Seed Dryer Prototype with Logic Control System and Arduino Mega 2560(Hasan, Herlina, \& Basri, 2019).Process Control Design for MicrocontrollerBased Coffee Bean Dryer System(Maulana, Jamaluddin, \& Finawan, 2018). Based on Arduino Uno Microcontroller and DS18B20 Sensor, Design of Agricultural Product Dryer by Convection with Infrared Heating Element(Hakim, Hasan, \& Syukriyadin, 2017). Nutmeg Seed Dryer System Prototype Based on Arduino Uno Microcontroller(Launda, Mamahit, \& Allo, 2017). Design of Microcontroller-Based Automatic Clothes Dryer and Dryer(Feriska \& Triyanto, 2017).Arduino-based soybean seed controller and dryer prototype with the website interface(Ramadani, Triyanto, \& Suhardi, 2018). Microcontroller based automatic vanilla dryer design(Supriyono, Ariwibowo, \& Irsyadi, 2015). Design of a shoe dryer based on humidity using the PID method(Rizkianto, 2019). Analysis of Design of Automatic Clothes Dryer(Ardi \& Amri, 2019). Design and build a salted fish drying control device for fishermen(Addari, 2019).

From all the backgrounds stated, this research will focus on the Design of Multilevel Mace Nutmeg Dryer to Improve the People's Economy to answer the problems that occur in the people of South Aceh regarding the dilemma of the drying process of mace nutmeg in the rainy season. 


\section{LITERATURE REVIEW}

From the studies that have been carried out by other researchers, including a prototype corn kernel dryer with logic and Arduino control(Hasan et al., 2019). Design and build a microcontroller-based coffee bean dryer controller(Maulana et al., 2018). Design of agricultural product drying machine with Arduino-based infrared heating element(Hakim et al., 2017). Arduino based nutmeg drying system prototype(Launda et al., 2017). Design and build an automatic clothes dryer and dryer based on a microcontroller(Feriska \& Triyanto, 2017).Arduinobased soybean seed controller and dryer prototype with website display(Ramadani et al., 2018). Design and build a salted fish drying control device for fishermen(Addari, 2019). Design of a shoe dryer based on humidity using the PID method(Rizkianto, 2019).Analysis of Design of Automatic Clothes Dryer(Ardi \& Amri, 2019). Arduino based automatic vanilla dryer design(Supriyono et al., 2015). Design and build an automatic grain dryer using a weight sensor based on Arduino Uno(Ikhsan, 2019). Design and build a seaweed dryer based on Arduino Uno(Ekayana, 2016).

In addition, research on dryers that use Arduino is also many other studies that use Arduino for their microcontrollers, such asRain Monitoring System for Nutmeg Drying(Ilham, Satria, Anugreni, Candra, \& Kusumo, 2021). Arduino based Heart Rate Monitoring and Stimulation(Ilham, Hardisal, Balkhaya, Candra, \& Sipahutar, 2019). Design of an Automatic Water Pump on a Traditional Boat (Ihsan, Ilham, Candra, Yunan, \& Hardisal, 2020). Designing an Arduino-based Automatic Cocoa Fermentation Tool (Balkhaya, Ilham, Candra, Hardisal, \& Hasbaini, 2020). Light Control Design by Using Social Media Telegram Applications Based on Internet Of Things (IOT) (Candra, Ilham, Hardisal, \& Sriwahyuni, 2019). The Infusion of Notification Design With an Application of Social Media Based on the Internet of Things (IOT) (Candra, Saputra, Ilham, Setiawan, \& Hardisal, 2020).

\section{METHOD}

Methods and steps of research work starting from the study of literature, determination of design specifications, hardware design, software design, toolmaking, testing tools.

\section{Hardware Requirements}

Table 1. Hardware specifications

\begin{tabular}{cll}
\hline Number & \multicolumn{1}{c}{ Name } & \multicolumn{1}{c}{ Function } \\
\hline 1 & Laptop/PC & As a place to run the Arduino Uno application forupload program \\
2 & Arduino Uno & As a system controller in the drying equipmentmace nutmeg \\
3 & Heating Element & As a converter of electrical energy into heat energy in drying \\
4 & DHT11 Sensor & to detect temperature and humidity conditions \\
5 & Relay & To control the electric current \\
6 & Jumper Cable & As a liaison between one component and another \\
7 & Fan Motor & Used to create airflow in order to speed up the drying process \\
8 & LCD & As displaying information on the results of drying mace nutmeg1 \\
9 & Breadboard & Used to make prototypes or electronic circuits that are experimental \\
10 & Blower Fan & Used to increase or increase the pressure of air or gas to be flowed \\
& & in a room and also as suction or vacuuming of air \\
11 & Power Supply & To provide voltage and electric current to other components \\
\hline
\end{tabular}

\section{Software Requirements}

Table 2. Software specifications

\begin{tabular}{cll}
\hline Number & \multicolumn{1}{c}{ Name } & \multicolumn{1}{c}{ Function } \\
\hline 1 & Fritzing.0.9.0b.32.pc & Used to simulate the circuit \\
2 & Microsoft Visio 2007 & Used to create block diagrams and flowcharts \\
3 & Arduino 1.8.12 windows & Used to upload programs \\
\hline
\end{tabular}

\section{Flow Chart Design}

The following is a flowchart of the design of the multi-storey mace nutmeg dryer: The flowchart following displays how the program's two processes work together:

1. The heating element will be started to dry the mace nutmeg in the oven once all of the circuits are completed.

*name of corresponding author 
2. If the DHT11 sensor detects a temperature of $45^{\circ} \mathrm{C}$, the heating element will cut off, and the cooling fan will turn on, with the display on the Liquid Crystal Display (LCD) displaying that everything is dry and ready to be removed.

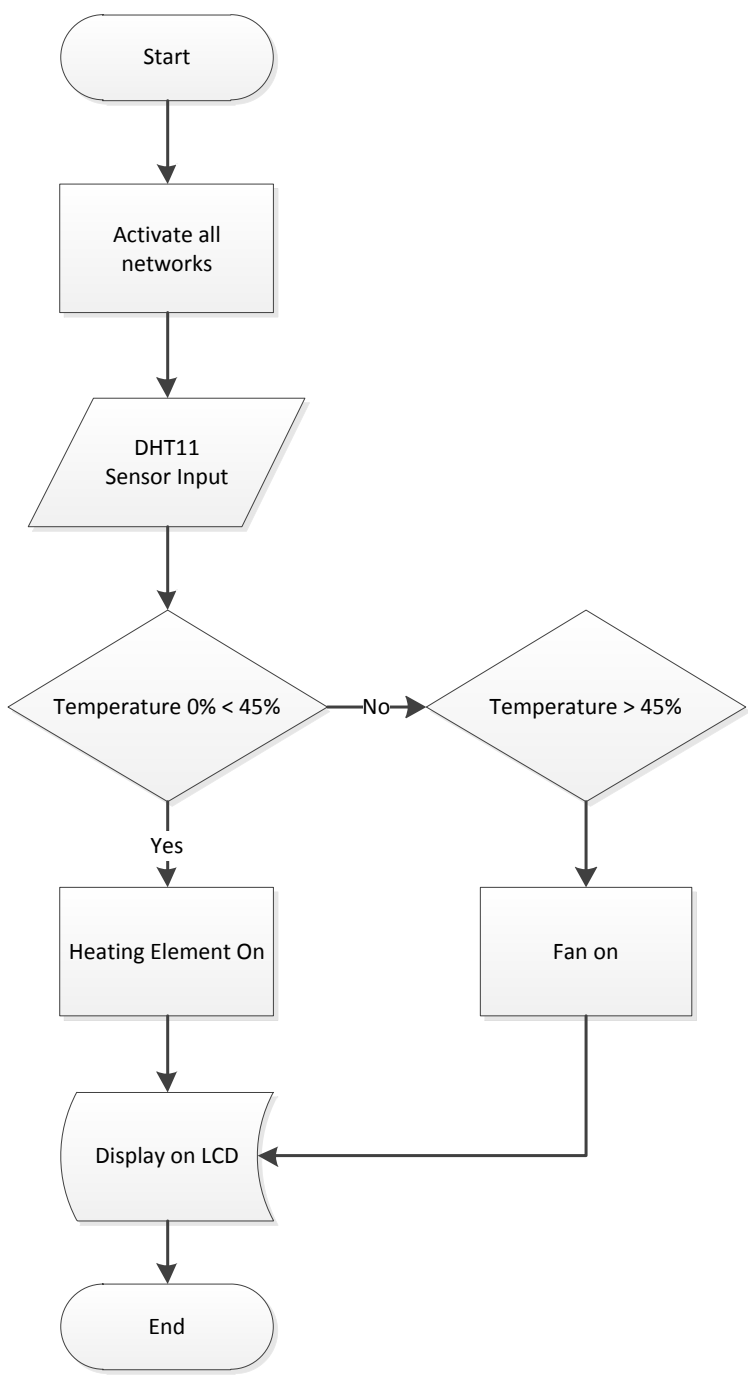

Figure 1. Flowchart of Program Flow

\section{Overall Toolkit}

RESULT

Automatic mace drying system from agricultural products in South Aceh, this system works based on input from a push button, where the input button pass will be received by Arduino as a system controller, giving orders to the relay as a heater control switch and a fan motor with a heater output, fan motor ON and OFF. 


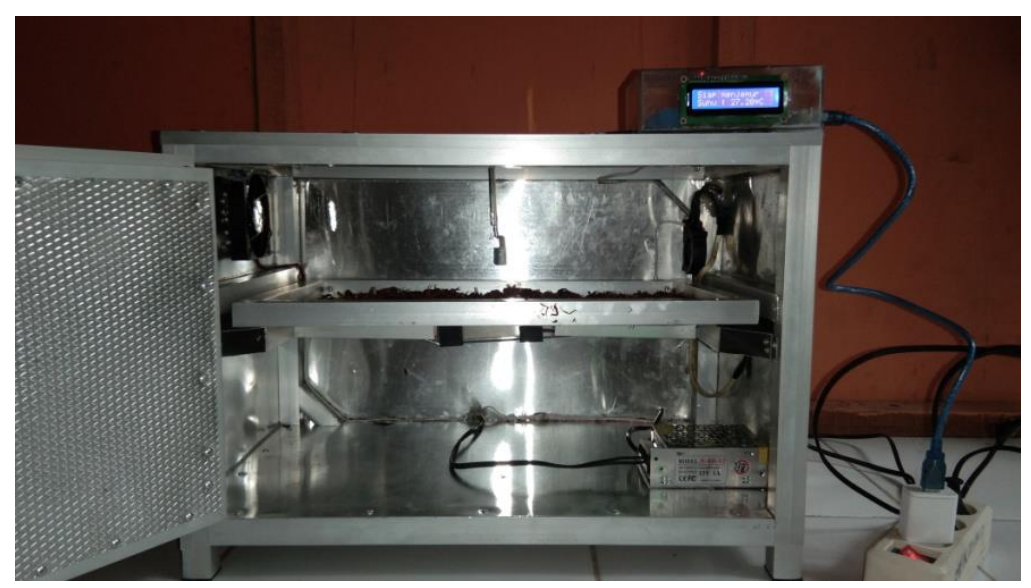

Figure 2. Overall Toolkit

\section{Overall Tool Test Results}

Test results display when the tool is started.

- The first display of tool testing when the tool starts to run can be shown in the following figure 3.

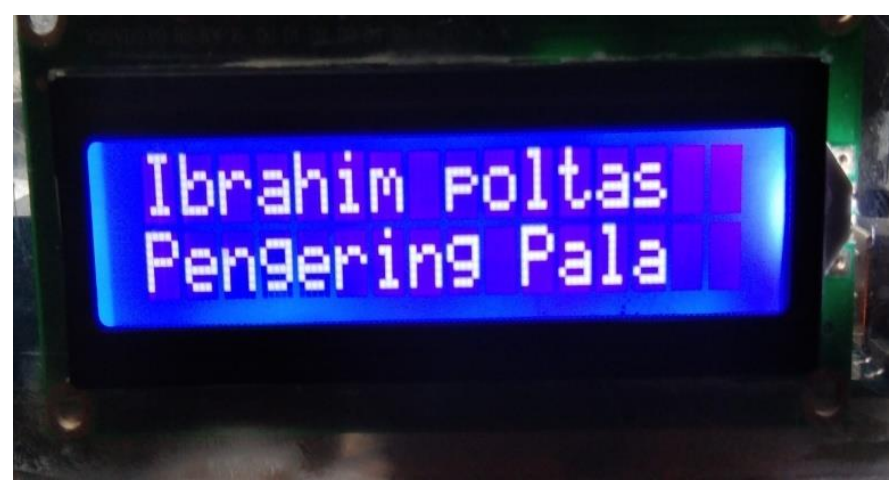

Figure 3. First View When the Tool Is Run

- The display drying test results when the Liquid Crystal Display (LCD) displays the drying character with an initial temperature of $28.00^{\circ} \mathrm{C}$ as shown in figure 4 .

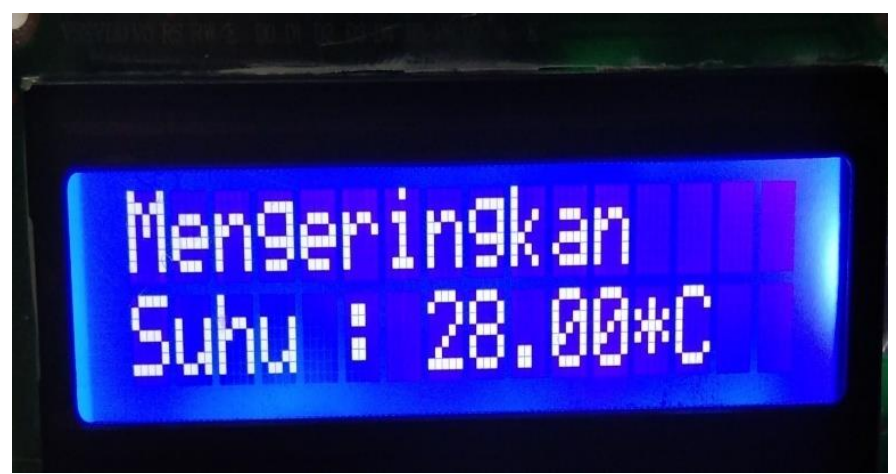

Figure 4. Drying Display

After putting the mace and clicking the pass button in the oven, the Liquid Crystal Display (LCD) displays the character of drying, showing that the hot temperature on the heater element in the oven is running or OFF, shown in the results above.

- The display of drying the test results of the tool when the LCD displays the drying character reaches $45 \%$ It can be seen in Figure 5. 


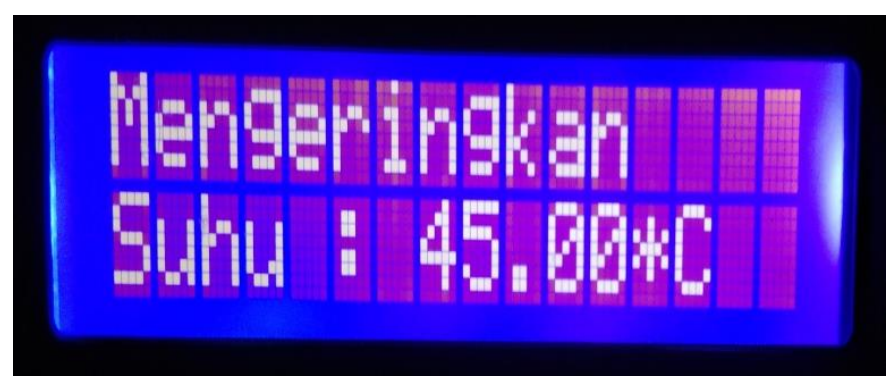

Figure 5. Cool View

From the picture above, it can be seen that the LCDs have a cooling character from the temperature limit reaching $45.00^{\circ} \mathrm{C}$, which means the heater heating element has been turned off and then replaced with a cooling period that the fan motor and blower fan are $\mathrm{ON}$ with the programmed temperature limit.

- The test results of the tool when the LCD displays the characters ready to be lifted can be shown in Figure 6.

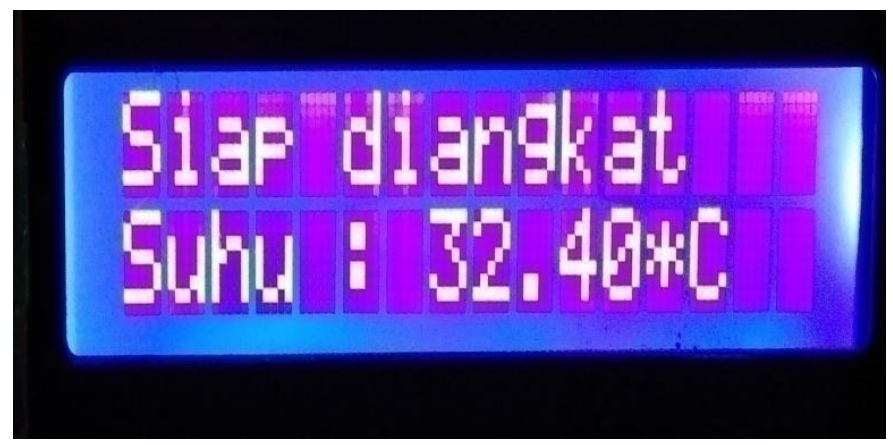

Figure 6. Display Ready to Lift

From the picture above, it can be seen that the LCDs the character ready to be lifted, which means that the fan and blower motors have been OFF and the drying results have been completed, so all the device systems in the oven have been turned OFF when drying again.

\section{Nutmeg Mace Drying Test in the Oven}

The following are the results of the test table for drying mace nutmeg with an experimental weight of 100 grams and also carried out at the same time at 09.00. In this test, to find the results of the nutmeg mace condition survey in the following table, it is possible to change the size of the heater and fan temperatures in the program.

Table 3. Drying Test of Nutmeg Mace in the Oven

\begin{tabular}{|c|c|c|c|c|c|c|}
\hline Test & $\begin{array}{c}\text { Room } \\
\text { temperature } \\
\left({ }^{0} \mathrm{C}\right)\end{array}$ & Drying Time & $\begin{array}{c}\text { Temperature in } \\
\text { drying condition } \\
\left({ }^{\circ} \mathrm{C}\right)\end{array}$ & $\begin{array}{l}\text { Cooling } \\
\text { Time }\end{array}$ & Condition & $\begin{array}{c}\text { Mace Nutmeg } \\
\text { Weight }\end{array}$ \\
\hline 1 & 28.08 & $\begin{array}{l}4 \text { Hours } 2 \\
\text { Minutes }\end{array}$ & 45 & 8 Minutes & Dry & 50 grams \\
\hline 2 & 28.02 & 2 Hours & 38 & 7 Minutes & Dry & 68 grams \\
\hline 3 & 28.04 & $\begin{array}{l}2 \text { Hours } 10 \\
\text { Minutes }\end{array}$ & 39 & 8 Minutes & Dry & 65 grams \\
\hline 4 & 28.05 & $\begin{array}{l}1 \text { Hours } 30 \\
\text { Minutes }\end{array}$ & 35 & 5 Minutes & Moist & 80 grams \\
\hline 5 & 28.06 & $\begin{array}{l}1 \text { Hours } 5 \\
\text { Minutes }\end{array}$ & 32 & 3 Minutes & Wet & 100 grams \\
\hline
\end{tabular}

\section{DISCUSSIONS}

According to Edi's statement, a nutmeg agent noticed that, while the nutmeg appeared dry when dried in the sun, the texture was more brittle and lighter after being dried using this automatic nutmeg mace dryer, and that the

*name of corresponding author 
drying time process could be calculated so that the supply capacity of dry nutmeg mace could be calculated. As an example, consider the drying process, which is based on the weather in nature.

\section{CONCLUSION}

Based on the results of the test results" in south Aceh on the design of an automatic mace drying device from agricultural products, it can be concluded that the system can dry mace nutmeg if all of the devices and push buttons are functional, and the system can provide hot temperatures to the heart all while to provide cold temperatures to the fan motor that has been installed.

\section{ACKNOWLEDGMENT}

Thank you to the Ministry of Education and Culture, Research, and Technology for funding this research through the Directorate General of Higher Education Research and Technology. And I am also very grateful for all my fellow lecturers in the beloved campus environment of the South Aceh Polytechnic.

\section{REFERENCES}

Addari, A. S. (2019). Rancang bangun alat kendali penjemur ikan asin bagi para nelayan. SKRIPSI.

Ardi, M., \& Amri, H. (2019). Analisa Rancang Bangun Alat Pengering Pakaian Otomatis. Journal of Electrical Electronic Control and Automotive Engineering (JEECAE), 4(1), 253-256.

Balkhaya, B., Ilham, D. N., Candra, R. A., Hardisal, H., \& Hasbaini, H. (2020). Designing an Arduino-based Automatic Cocoa Fermentation Tool. SinkrOn, 5(1), 92-99. https://doi.org/10.33395/sinkron.v5i1.10611

Candra, R. A., Ilham, D. N., Hardisal, H., \& Sriwahyuni, S. (2019). Light Control Design by Using Social Media Telegram Applications Based on Internet Of Things (IOT). SinkrOn, 3(2), 200. https://doi.org/10.33395/sinkron.v3i2.10094

Candra, R. A., Saputra, D. S., Ilham, D. N., Setiawan, H., \& Hardisal, H. (2020). The Infusion of Notification Design With an Application of Social Media Based on a Internet of Things (IOT). SinkrOn, 5(1), 129. https://doi.org/10.33395/sinkron.v5i1.10610

Ekayana, A. A. G. (2016). RANCANG BANGUN ALAT PENGERING RUMPUT LAUT BERBASIS MIKROKONTROLER ARDUINO UNO. JPTK, UNDIKSHA, 13(1), 1-12.

Feriska, A., \& Triyanto, D. (2017). Rancang Bangun Penjemur dan Pengering Pakaian Otomatis Berbasis Mikrokontroler. 05(2).

Hakim, E. Z. R., Hasan, H., \& Syukriyadin. (2017). Perancangan Mesin Pengering Hasil Pertanian Secara Konveksi dengan Elemen Pemanas Infrared Berbasis Mikrokontroler Arduino Uno dengan Sensor DS18B20. 2(3), 16-20.

Hasan, S., Herlina, A., \& Basri, M. H. (2019). Prototipe Mesin Pengering Biji Jagung dengan Sistem Kendali Logika dan Arduino Mega 2560. 1(3), 108-117. https://doi.org/10.12928/biste.v1i3.1099

Ihsan, I., Ilham, D. N., Candra, R. A., Yunan, A., \& Hardisal, H. (2020). Design of an Automatic Water Pump on a Traditional Boat. SinkrOn, 5(1), 100. https://doi.org/10.33395/sinkron.v5i1.10635

Ikhsan, M. (2019). RANCANG BANGUN ALAT PENGERING GABAH OTOMATIS MENGGUNAKAN SENSOR BERAT BERBASIS ARDUINO UNO. Laporan Tugas Akhir.

Ilham, D. N., Hardisal, H., Balkhaya, B., Candra, R. A., \& Sipahutar, E. (2019). Heart Rate Monitoring and Stimulation with the Internet of Thing-Based (IoT) Alquran Recitation. SinkrOn, 4(1), 221. https://doi.org/10.33395/sinkron.v4i1.10392

Ilham, D. N., Satria, E., Anugreni, F., Candra, R. A., \& Kusumo, H. N. R. A. (2021). Rain Monitoring System for Nutmeg Drying Based on Internet of Things. Journal of Computer Networks, Architecture, and HighPerformance Computing, 3(1), 52-57. https://doi.org/10.47709/cnahpc.v3i1.933

Launda, A. P., Mamahit, D. J., \& Allo, E. K. (2017). Prototipe System Pengering Biji Pala Berbasis Mikrokontroler Arduino Uno. 6(3), 141-147.

Maulana, R., Jamaluddin, \& Finawan, A. (2018). Rancang Bangun Pengendalian Proses pada Sistem Pengering Biji Kopi Berbasis mikrokontroler. Laporan Tugas Akhir, 2(2).

Ramadani, F., Triyanto, D., \& Suhardi. (2018). PROTOTYPE ALAT PENGONTROL DAN PENGERING BENIH KEDELAI BERBASIS ARDUINO DENGAN ANTARMUKA WEBSITE. 06(03), 107-117.

Rizkianto, A. B. (2019). Rancang Bangun Pengering sepatu Berdasarkan Kelembaban Menggunakan Metode PID. Laporan Tugas Akhir.

Supriyono, H., Ariwibowo, S., \& Irsyadi, F. Y. Al. (2015). RANCANG-BANGUN PENGERING PANILI OTOMATIS BERBASIS MIKROKONTROLER. Simposium Nasional RAPI XIV - 2015 FT UMS, 50-56.

*name of corresponding author

This is an Creative Commons License This work is licensed under a Creative

Commons Attribution-NonCommercial 4.0 International License. 